\title{
Cadmium Accumulation in Soil and in Some Vegetable Crops induced by Phosphate Fertilizer
}

\author{
El-Garawany, M. M ${ }^{1}$ and M. R. Mahmoud ${ }^{2}$
}

\begin{abstract}
To evaluate the impact of four levels of phosphorus fertilizer on cadmium (Cd) accumulation in soil and in the vegetative parts of tomato (Lycopersicum esculentum $L$.), lettuce (Lactuca sativa L.) and radish (Raphanus sativus $L$.), three field experiments using loamy sandy soil, in West Al-Nubaria area, Abu-El-Atta Village, were conducted in 2004 and 2005 winter seasons. The levels of triple superphosphate fertilizer $\left(45-47 \% \quad \mathrm{P}_{2} \mathrm{O}_{5}\right)$ used were $0,100,200$, and $300 \mathrm{~kg} \mathrm{P}_{2} \mathrm{O}_{5} /$ fed (fed = fedan $=4200 \mathrm{~m}^{2}$ ). Different rates of triple super-phosphate had significant effects on $\mathrm{Cd}$ concentration in the plant tissues of the three studied crops. Phosphate increased Cd accumulation in plant parts, with more evident effect with the highest rate. The range of $\mathrm{Cd}$ concentration in tomato fruit juice $\left(0.08-0.12 \mathrm{mg} \mathrm{kg}^{-1}\right)$ was higher than that in tomato fruit flesh $\left(0.009-0.020 \mathrm{mg} \mathrm{kg}^{-1}\right)$. Cd concentration in radish ranged between $0.65-0.76 \mathrm{mg}$ $\mathrm{kg}^{-1}$ which was higher than that in lettuce $0.12-0.24 \mathrm{mg}$ $\mathrm{kg}^{-1}$ or in tomato fruits $\left(0.100-0.176 \mathrm{mg} \mathrm{kg}^{-1}\right)$ at the applied levels of phosphate fertilizer. In lettuce plants, the Cd concentration in root was higher than that of shoots while the opposite was found in radish plants. Soil available cadmium and phosphorus levels after harvest increased significantly with increasing application rates of phosphorus in the three experiments.

The application of phosphate fertilizer, although it had notable benefits to soil fertility, it was associated with possible negative effects due to increased $P$ availability and Cd accumulation which affect both soil water quality and soil ecology.
\end{abstract}

Keywords: Fertilizer, cadmium, phosphate, phosphorus, tomato, lettuce, radish.

\section{INTRODUCTION}

To face the problem of entrance of potentially toxic heavy metals in the soil-plant ecosystem, which could have negative effects on the environment along with occasional irreversible pollution, effective soil management and soil biology measures must be taken into account. There is some indirect evidence of possible heavy metal build-up in some agricultural soils because of long-term application of inorganic phosphate fertilizers (Ewa et al., 1999). Trace elements are normally found in phosphate fertilizers (Lee et al., 1997,

1 Soil fertility\& plant nutrition Res. Dept. Soil Water and Environmental Research Institute, , Agric Res. Center. Cairo, Egypt

${ }^{2}$ Vegetable Department, Horticulture Research Institute,.

Agric Res. Center. Cairo, Egypt

Received May 20 ,2007 Accepted June 22, 2007.
Todorova and Dombalov, 1995) and fertilization for long periods increases their concentration in soils (He and Singh, 1993 and Taylor, 1997). These elements are absorbed by plants and some are contaminants, which might become a risk for the environment and health. Among these elements $\mathrm{Cd}, \mathrm{Cr}, \mathrm{Ni}, \mathrm{Pb}$ and the micronutrients $\mathrm{Cu}$ and $\mathrm{Zn}$ can be mentioned (Lee et al., 1997 and Jeng and Singh, 1993). Of the heavy metals cadmium (Cd) is considered a widespread contaminants (Oliver, 1997). Cadmium is one of the most dangerous heavy metals for its high mobility and its presence in small concentrations which may show toxic effects on sensitive plants (Barcelo and Pochenrieder, 1990). This heavy metal poses considerable threats to public health, since it can readily and easily be transferred to edible portions of food crops than that of other contaminant elements (Zarcinas et al., 1996). Cd is especially dangerous because of its ability to accumulate in plants in large quantities without any visible signs (Lehoczky et al. 1996).

The uptake of $\mathrm{Cd}$ by plant tissues increases with increasing application rate of phosphate fertilizers (Pezzarossa et al., 1993). Thus, Cd increase in soil will leads to its increase in crop plants (Webber, 2003). The $\mathrm{Cd}$ accumulation in plant tissues varies with crop species and plant part (Moral et al., 1994). Cd has the ability to be transferred to aerial parts of tomato plants (Moral et al., 1994). Lettuce, also, can accumulate Cd in its leaves in high concentrations (Lehoczky et al. 1996; Lehoczky and Horvath 1998). Broad-leaved vegetables such as lettuce, accumulate more cadmium than most other plants (Webber, 2003).

The objective of this study was to investigate the impact of heavy phosphate fertilizer application on the distribution and accumulation of $\mathrm{Cd}$ in three vegetable crop plants (tomato, radish, and lettuce).

\section{MATERIALS AND METHODS}

The effects of different levels of super-phosphate have been evaluated in three field experiments in 2004/2005, on tomato (cv. Carmello), lettuce (cv. Dark green) and radish (cv.Baldy) at the West Al-Nubaria 
area, Abu-El-Atta Village. The soil has loamy sand texture (82\% sand, $7 \%$ silt and $11 \%$ clay) and, initially, $7.8 \mathrm{pH}, 0.54 \mathrm{dS} / \mathrm{m} \mathrm{EC}$, available phosphorus was $5 \mathrm{mg}$ $\mathrm{kg}^{-1}$ and available $\mathrm{Cd}$ was $0.0085 \mathrm{mg} \mathrm{kg}^{-1}$. Phosphate fertilizer was applied in the form of triple superphosphate $\left(45-47 \% \mathrm{P}_{2} \mathrm{O}_{5}\right)$. Fertilization treatments have been repeated on the same plots. The Cd content in triple superphosphate was analyzed and its value was $2.9 \mathrm{ppm}$. Phosphate treatments were to supply 0,100 , 200, $300 \mathrm{~kg} \mathrm{P}_{2} \mathrm{O}_{5} / \mathrm{fed}$. There was one crop for each experiment. The four fertilization treatments were arranged in a randomized complete block design with four replicates. The total number of plots/crop was 16 . The experimental unit was 10 rows, each 10 meter long with $25 \mathrm{~cm}$ between rows.

According to the most suitable sowing dates, tomato was planted on $12^{\text {th }}$ November, while radish and lettuce were grown on $11^{\text {th }}$ and $19^{\text {th }}$ of February respectively each year. The treatments were broadcast in three equal doses, at 4, 7, and 10 weeks after planting. All other agricultural practices were applied as recommended for commercial production of these crops.

At harvest, five plants were taken as a random sample from each plot. Vegetative parts (leaves, stems, and roots) were cut, washed with tap water and rinsed with deionised water and dried at $70^{\circ} \mathrm{C}$ in a drying oven to a constant weight and ground using a gate mill for chemical analysis.

\section{Plant and soil analysis}

Subsamples of ground stem samples $(200 \mathrm{mg})$, leaves samples $(200 \mathrm{mg})$ and root samples $(100 \mathrm{mg})$ were digested in a mixture of concentrated $\mathrm{HNO}_{3}$ and $\mathrm{HClO}_{4}$ (4:1, by volume) and the $\mathrm{P}$ and $\mathrm{Cd}$ elements in the solution were determined with ICP-AES (Chen et al., 2004). A certified standard reference material (SRM 1515, apple leaves) of the National Institute of Standards and Technology, USA, was used in the digestion and analysis as part of the QA/QC protocol (Quality Assurance/Quality Control according to EPA protocol). Reagent blank and analytical duplicates were also used where appropriate to ensure accuracy and precision in the analysis. The recovery rates were around $90 \square 6 \%$ for $\mathrm{Cd}$ and $\mathrm{P}$ in the plant reference material. Soil samples were digested first with $65 \%$ and $72 \% \mathrm{HClO}_{4}$ (Walts, 1971) and then, with $40 \% \mathrm{HF}$. The 'plant available' metal concentrations in soil were determined after extraction with 0.005 M DTPA (Lindsay and Norvell, 1978). All plant and soil materials digested and soil extracts were analyzed for $\mathrm{Cd}$, using inductively coupled plasma spectromertry (ICP-MS). The data reported in this paper were the mean values of the four replicates.

\section{Statistical analysis}

Data were subjected to the statistical analysis of variance and when the $F$ ratio was significant, the least significant difference (LSD) test was applied using the SPSS statistical package version 9.0 for Windows 98 to compare treatments means. Using the same data, a correlation analysis was also calculated, to evaluate the extent of association and its significance.

\section{RESULTS AND DISCUSSION}

\section{Cadmium concentration in tomato plant}

The results of the present study revealed that $\mathrm{Cd}$ content of tomato plant parts increased with increasing phosphate fertilization level as compared with the untreated control (Table 1). Thus, the Cd level in plant tissues depends on the concentration of available $\mathrm{Cd}$ in the soil corroborating earlier results on rice, Oryza sativa L.; sweet corn, Zea mays L. and tomato, Lycopersicon esculentum (Reddy and Patrick, 1977 and Mahler et al., 1980).

The results presented in Table 1, also showed that the distribution of the metal taken up is not homogenous, where a higher proportion remains in the roots than is transported to the shoots. This observation is also in agreement with those reported by Petterson (1976) who indicated that when cucumber, Cucumis sativus L.; wheat, Triticum aestivum L.; Oat, Avena sativa $\mathrm{L}$. and tomato, Lycopersicon esculentum $\mathrm{L}$. were grown in nutrient solution with 1,10 and $100 \mu \mathrm{M} \mathrm{Cd}$, the shoot and root content of Cd increased 5-10 times if the metal concentration was increased 10 times.

The results also demonstrated that $\mathrm{Cd}$ content was highest in the roots (Table 1) and decreases during ontogenesis (Table 1). Thus, the root system of tomato seems, to act as the first barrier to $\mathrm{Cd}$ in the soil. In spite of the different mobility of metals in plants, the root system accumulates them to a significantly higher extent than do the above ground organs and as a result it is one of the targets of their toxic effect. Similar conclusion was drawn by Ernst et al. (1992).

There are significant differences in the $\mathrm{Cd}$ concentration in different parts of the plants. However, the variation of $\mathrm{Cd}$ concentration as a function of the rate of application of phosphate fertilizer did show a clear cut. Cd concentration in various plants parts is generally higher at $200 \mathrm{~kg} \mathrm{P}_{2} \mathrm{O}_{5} / \mathrm{fed}$ treatment. However, the increase of the $\mathrm{Cd}$ concentration at other $\mathrm{P}_{2} \mathrm{O}_{5}$ levels was not significant between treatments. The $\mathrm{Cd}$ concentrations were in the following order: flesh < juice < roots + shoots. The concentrations of $\mathrm{Cd}$ ranged between 0.009 and $0.020 \mathrm{mg} \mathrm{kg}^{-1}, 0.08$ and $0.120 \mathrm{mg} \mathrm{kg}^{-1}$ and 0.212 and $0.387 \mathrm{mg} \mathrm{kg}^{-1}$ in tomato flesh, juce and roots + shoots, respectively. These results illustrated that vegetative parts especially the roots restricted the 
transportation of the ion to tomato fruits and reduced its accumulation in the tomato fruits. In other words, $\mathrm{Cd}$ was preferentially accumulated in roots and shoots with low transport to fruits. The data revealed that the concentration of $\mathrm{Cd}$ in different tissues of tomato plants raised with increasing phosphorus. In general, the pronounced concentration of $\mathrm{Cd}$ in vegetative parts of tomato may be due to the presence of $\mathrm{Cd}$ in phosphate fertilizer, which increased with increasing application rate. Increasing phosphate fertilizer application increased soil DTPA-extractable Cd. This would have been responsible for increasing the uptake of $\mathrm{Cd}$ by tomato plants, and the accumulation in the vegetative parts, indicated the existence of a reduced translocation of this metal from the vegetative to the reproductive organs. These results are in agreement with those of Pezzarossa et al. (1993). ACMS (2003) reported that Health authorities have set an upper limit for cadmium in root, tuber and leafy vegetables. This is called the 'Maximum Permitted Concentration (MPC)' and is set at 0.1 milligrams per kilogram $(\mathrm{mg} / \mathrm{kg})$ of fresh weight.

\section{Cadmium concentration in lettuce plant}

Data presented in Table 2 indicated that $\mathrm{Cd}$ concentrations in leaves and roots of lettuce plant after harvest varied between a minimum of $0.07 \mathrm{mg} \mathrm{kg}^{-1}$ and a maximum of $0.3 \mathrm{mg} \mathrm{kg}^{-1}$ in response to application of different levels of $\mathrm{P}_{2} \mathrm{O}_{5}$. The data indicated that generally, $\mathrm{Cd}$ concentrations in both leaves and roots increased with the increase of $\mathrm{P}_{2} \mathrm{O}_{5}$ level. Significant differences were found between $\mathrm{P}_{2} \mathrm{O}_{5}$ treatments but no significant different in $\mathrm{Cd}$ content in leaves were observed between treatments 100 and $200 \mathrm{~kg} \mathrm{P}_{2} \mathrm{O}_{5} / \mathrm{fed}$ and also, in the roots no significant differences were found between 0 and $100 \mathrm{~kg} \mathrm{P}_{2} \mathrm{O}_{5} / \mathrm{fed}$ and between 200 and $300 \mathrm{~kg} \mathrm{P}_{2} \mathrm{O}_{5} /$ fed treatments. In the whole plant, the $\mathrm{Cd}$ content was not significantly different between the 200 and the $300 \mathrm{~kg} \mathrm{P}_{2} \mathrm{O}_{5} /$ fed treatments. The maximum concentration of $\mathrm{Cd}$ was found at the $100 \mathrm{~kg} \mathrm{P}_{2} \mathrm{O}_{5} / \mathrm{fed}$ level in the leaf and root samples. The results showed that $\mathrm{P}_{2} \mathrm{O}_{5}$ application caused a significant build up of $\mathrm{Cd}$ in roots than in leaves at the applied levels of $\mathrm{P}_{2} \mathrm{O}_{5}$. The $\mathrm{Cd}$ concentration in leaves ranged between 0.07 at zero treatment and $0.13 \mathrm{mg} \mathrm{kg}^{-1}$ at $300 \mathrm{~kg} \mathrm{P}_{2} \mathrm{O}_{5} / \mathrm{fed}$, whereas in roots, it varied between 0.16 and $0.37 \mathrm{mg} \mathrm{kg}^{-1}$. This can be attributed to the enrichment in $\mathrm{Cd}$ in the soil from phosphate fertilizer which consequently increased $\mathrm{Cd}$ concentration in plant tissues. These results are in agreement with the finding of Moral et al. (1994) and Pezzarossa et al. (1993). The Data of Table 2, also showed that $\mathrm{P}_{2} \mathrm{O}_{5}$ fertilization increased $\mathrm{Cd}$ accumulation in the roots more than its accumulation in the leaves. The results also indicated that lettuce roots observed $\mathrm{Cd}$ from the soil and transport it to the shoots to different degrees, but most of the absorbed $\mathrm{Cd}$ remains in the root or redistributed to the root from the shoots. This suggestion is confirmed by the study of Cataldo et al., (1983) who reported that normally Cd ions are mainly retained in the roots, and only small amounts are transported to the shoots. Greger and Lindberg (1986) reported a $4-10$ times increase in the Cd content of sugar beet, Beta vulgaris L., roots when $\mathrm{Cd}$ concentration was raised from $5-10 \mu \mathrm{M}$. They also found that the $\mathrm{Cd}$ content of the shoots was only $10-$ $20 \%$ of that of the roots. A similar behavior was observed when weeds were grown in clay soil and irrigated with different concentration $(5,10,20 \mathrm{mg} / \mathrm{kg})$ of Cd (Ewais, 1997). The author further revealed that most of the Cd was accumulated in roots (81\%) and only $19 \%$ were transported to the shoots. In this respect, lettuce plant may be considered as 'Cd shoot excluders' with $\mathrm{Cd}$ accumulating at higher concentrations in roots than in shoots. This behaviour is one of several strategies for plants to tolerate Cd (Weigel and Jager, 1980). This may be due to the hindrance of the transportation of $\mathrm{Cd}$ to the leaves. This claim contradicts the findings of Moral et al. (1994).

\section{Table 1. Effect of phosphate fertilizer treatments on $\mathrm{Cd}$ concentration in tomato cultivar "Carmalo"}

\begin{tabular}{|c|c|c|c|c|}
\hline \multirow{3}{*}{$\begin{array}{l}\text { Phosphorus Treatment } \\
\left(\mathrm{kg} \mathrm{P}_{2} \mathrm{O}_{5} / \text { fed }^{*}\right)\end{array}$} & \multicolumn{4}{|c|}{$\mathrm{Cd}\left(\mathrm{mg} \mathrm{kg}^{-1}\right)$} \\
\hline & \multicolumn{2}{|c|}{ Fruits } & \multirow[b]{2}{*}{$\begin{array}{l}\text { Roots }+ \\
\text { Shoots }\end{array}$} & \multirow[b]{2}{*}{ Whole plant } \\
\hline & Juice & Flesh & & \\
\hline 0 & 0.080 & 0.009 & 0.212 & 0.100 \\
\hline 100 & 0.090 & 0.010 & 0.228 & 0.109 \\
\hline 200 & 0.100 & 0.015 & 0.228 & 0.114 \\
\hline 300 & 0.120 & 0.020 & 0.387 & 0.176 \\
\hline $\mathrm{LSD}_{0.05}$ & 0.032 & 0.004 & 0.057 & 0.029 \\
\hline
\end{tabular}

fed is fedan $=4200 \mathrm{~m}^{2}$,

${ }^{* *} \mathrm{LSD}_{0.05}$ : Least significant differences at 0.05 significant level 
Table 2. Effect of phosphate fertilizer treatments on the Cd concentration in lettuce cultivar "dark green".

\begin{tabular}{|c|c|c|c|}
\hline \multirow{2}{*}{$\begin{array}{l}\text { Phosphorus Treatment } \\
\left(\mathrm{kg} \mathrm{P}_{2} \mathrm{O}_{5} / \mathrm{fed}^{*}\right)\end{array}$} & \multicolumn{3}{|c|}{$\mathrm{Cd}\left(\mathrm{mg} \mathrm{kg}^{-1}\right)$} \\
\hline & Leaves & Roots & Whole plant \\
\hline 0 & 0.07 & 0.16 & 0.12 \\
\hline 100 & 0.08 & 0.23 & 0.17 \\
\hline 200 & 0.11 & 0.34 & 0.03 \\
\hline 300 & 0.13 & 0.37 & 0.24 \\
\hline $\mathrm{LSD}_{0.05}{ }^{* *}$ & 0.02 & 0.07 & 0.04 \\
\hline
\end{tabular}

fed is fedan $=4200 \mathrm{~m}^{2}$

${ }^{* *} \mathrm{LSD}_{0.05}$ : Least significant differences at 0.05 significant level

\section{Cadmium concentration in radish plant}

Table 3 showed the effect of applying $\mathrm{P}_{2} \mathrm{O}_{5}$ at four different levels $\left(0,100,200\right.$, and $300 \mathrm{~kg} \mathrm{P}_{2} \mathrm{O}_{5} /$ fed) on the $\mathrm{Cd}$ concentration in radish plants. The concentration of $\mathrm{Cd}$ in the leaves was $0.78 \mathrm{mg} \mathrm{kg}^{-1}$ at 0 level of $\mathrm{P}$ and reached $1.04 \mathrm{mg} \mathrm{kg}^{-1}$ at $300 \mathrm{~kg} \mathrm{P}_{2} \mathrm{O}_{5} /$ fed of P. Statistical analysis revealed significant increases in $\mathrm{Cd}$ concentration of leaves with increasing levels of phosphorus treatments with respect to control plants. However, when the $\mathrm{P}_{2} \mathrm{O}_{5}$ level is increased from 200 to $300 \mathrm{~kg} / \mathrm{fed}$, the resultant increase in Cd concentration in leaves is not significant. No significant variations were observed in Cd concentration in the roots between $\mathrm{P}_{2} \mathrm{O}_{5}$ treatments. The $\mathrm{Cd}$ concentrations ranged between 0.51 $\mathrm{mg} \mathrm{kg}{ }^{-1}$ and $0.54 \mathrm{mg} \mathrm{kg}^{-1}$ at $200 \mathrm{~kg} \mathrm{P}_{2} \mathrm{O}_{5} / \mathrm{fed}$ and $300 \mathrm{~kg}$ $\mathrm{P}_{2} \mathrm{O}_{5} / \mathrm{fed}$, respectively. The data showed that the leaves accumulated more $\mathrm{Cd}$ than roots under all levels of $\mathrm{P}$. This tendency towards increasing $\mathrm{Cd}$ concentration in leaves may be attributed to active transport. These findings are in agreement with the study of Pezzarossa et al. (1993). They reported that the application of Cd bearing phosphate fertilizer increased the $\mathrm{Cd}$ level in soils and plants. These results also are in agreement with the findings of Moral et al. (1994) and Webber (2003), who reported that $\mathrm{Cd}$ accumulation in plant materials varies with crop type and plant part and $\mathrm{Cd}$ has the ability to be transported to aerial parts. Also, Petterson (1976) claimed that there were significant differences between plant species in their response to different $\mathrm{Cd}$ concentration.

Another view was postulated by Schierup and Larsen (1981) who reported that differences in the ability of plants to accumulate heavy metals is related to differences in their root morphology. The investigators suggested that a plant with numerous roots would accumulate more metals than one with few thick roots.

In conclusion, the results of the present investigation showed that most of the $\mathrm{Cd}$ absorbed is mainly accumulated in the roots of tomato and lettuce plant, while it is translocate freely to the leaves in case of radish. Comparing $\mathrm{Cd}$ concentration in the three plants at different levels of $\mathrm{P}_{2} \mathrm{O}_{5}$ revealed that the radish plant accumulated more $\mathrm{Cd}$ than both of lettuce and tomato plants. Radish plants accumulated $\mathrm{Cd}$ from 4.3 to 7.8 times more than tomato plants, while in lettuce plants the range was from 3.23 to 5.6 times. Our results are in close agreement with those reported by Webber (2003) who reported that broad-leaved vegetables accumulate more cadmium than most other plants.

\section{Cadmium and phosphorus concentrations in the soil}

Table 4 shows the average content of $\mathrm{Cd}$ and $\mathrm{P}$ in soils of the three crops. The ranges of available $\mathrm{Cd}$ in the soil were $0.40-0.45 \mathrm{mg} \mathrm{kg}^{-1}$ and $0.38-0.44 \mathrm{mg} \mathrm{kg}^{-1}$ in soils of radish and lettuce, respectively. The same trend was observed for available $\mathrm{P}$ in the soil with increasing $\mathrm{P}_{2} \mathrm{O}_{5}$ levels. Available $\mathrm{P}$ varied from 5.32 to $17.2,5.3$ to 9.7 and 5.0 to $7.3 \mathrm{mg} \mathrm{kg}^{-1}$ in the soils of tomato, radish and the lettuce respectively. The variation of $\mathrm{Cd}$ and $\mathrm{P}$ in the soils might be due to the amounts of phosphate fertilizer added to the soil.

Significant positive correlation coefficients $(0.975$, 0.921 and 0.898 ) were found between available $\mathrm{P}$ and $\mathrm{Cd}$ in the three experiments, which could be due to the presence of this heavy metal in the phosphate fertilizer as contaminant (Nicholson and Jones, 1994 and Gimeno-Garcia et al., 1996). Also a positive and significant correlation coefficient (0.737) was found between the concentration of $\mathrm{Cd}$ in plants and the available $\mathrm{P}$ of all experimental soils. It could be concluded that the excess $\mathrm{P}$ helps in the accumulation of $\mathrm{Cd}$ in both soil and vegetative parts of tomato, lettuce and radish. Similarly, Pezzarossa et al. (1993) observed that $\mathrm{Cd}$ concentration in edible parts of plants was dependent on $\mathrm{P}_{2} \mathrm{O}_{5}$ application.

Environmental quality cannot be ensured by simply controlling the concentration of heavy metals added therein, because soils make up a complicated and hetero generous system (Chen et al., 2001). 
Table 3. Effect of phosphate fertilizer treatments on the $\mathrm{Cd}$ concentration in radish cultivar "Baldy"

\begin{tabular}{|c|c|c|}
\hline \multirow{2}{*}{$\begin{array}{l}\text { Phosphorus Treatment } \\
\left(\mathrm{kg} \mathrm{P}_{2} \mathrm{O}_{5} / \text { fed }^{*}\right)\end{array}$} & \multicolumn{2}{|c|}{$\mathrm{Cd}\left(\mathrm{mg} \mathrm{kg}^{-1}\right)$} \\
\hline & leaves & Roots \\
\hline 0 & 0.78 & 0.51 \\
\hline 100 & 0.90 & 0.52 \\
\hline 200 & 1.01 & 0.52 \\
\hline 300 & 1.04 & 0.54 \\
\hline $\mathrm{LSD}_{0.05^{* *}}$ & 0.04 & 0.03 \\
\hline
\end{tabular}

fed is fedan $=4200 \mathrm{~m}^{2}$,

${ }^{* *} \mathrm{LSD}_{0.05}$ : Least significant differences at 0.05 significant level

Table 4. Effect of phosphate treatments on the concentration of available $P$ and $C d$ in sandy soils after harvesting tomato, lettuce and radish plant

\begin{tabular}{|c|c|c|c|}
\hline \multirow{2}{*}{$\begin{array}{c}\text { Phosphorus } \\
\text { Treatment } \\
\left(\mathrm{kg} \mathrm{P}_{2} \mathrm{O}_{5} / \mathrm{fed}\right)\end{array}$} & \multicolumn{2}{|c|}{ Available element $\left(\mathrm{mg} \mathrm{kg}^{-1}\right)$ in soil } & \multirow{2}{*}{$\begin{array}{l}\text { Correlation coefficient } \\
\text { between } P \text { and } C d\end{array}$} \\
\hline & $\mathbf{P}$ & Cd & \\
\hline \multicolumn{4}{|c|}{ tomato plant experiment } \\
\hline 0 & 5.31 & 0.40 & \\
\hline 100 & 13.2 & 0.40 & \\
\hline 200 & 14.7 & 0.45 & \\
\hline 300 & 17.2 & 0.51 & $0.975^{*}$ \\
\hline \multicolumn{4}{|c|}{ radish plant experiment } \\
\hline 0 & 5.3 & 0.40 & \\
\hline 100 & 7.8 & 0.41 & \\
\hline 200 & 8.5 & 0.43 & \\
\hline 300 & 9.7 & 0.45 & $0.921^{*}$ \\
\hline \multicolumn{4}{|c|}{ lettuce plant experiment } \\
\hline 0 & 5.3 & 0.40 & \\
\hline 100 & 6.3 & 0.39 & \\
\hline 200 & 6.5 & 0.42 & \\
\hline 300 & 7.3 & 0.44 & $0.898^{*}$ \\
\hline
\end{tabular}

Correlation coefficient between $\mathrm{Cd}$ of leaves and available $\mathrm{P}$ in soil is $0.737^{*}$

There are other criteria to evaluate soil contamination by heavy metals such as background concentrations which represents natural elemental concentration in soils without human influence (Chen et al., 1999). The base line background concentration of $\mathrm{Cd}$ in this study is 0.40 and the treated soils of the three crops slightly surpass the background level of cadmium. However, soil contamination may be considered when concentration of an element in soils is two or three times greater than the mean background levels (Logan and Miller, 1983) and none of the treatments reached that level.

The concentration of $\mathrm{Cd}$ in soils of the experimental site increased slightly due to the application of phosphate fertilizers, but the concentration did not reach contamination levels in the three experiments. An intensive increase of phosphate fertilizer application lead to the accumulation of available $\mathrm{Cd}$ in the soil that in turn affects the $\mathrm{Cd}$ content in plants. The data showed that significant correlations between available $\mathrm{P}$ and $\mathrm{Cd}$ both in soil and plant tissue. The ability of plant to accumulate $\mathrm{Cd}$ may depend on crop type and plant part. To avoid the side effects or toxicity of $\mathrm{Cd}$ on animals and humans, we recommend using fertilizers low in cadmium and avoiding overuse of $\mathrm{P}_{2} \mathrm{O}_{5}$ fertilizers.

\section{REFERENCES}

ACMS, 2003. Australian Cadmium Minimization Strategy, availableathttp://www.cadmium- management.org.au/about.html

Barcelo J. and C. H. Poschenrieder. 1990. Plant water relations as affected by heavy metal stress: a review. J. 
plant nutrition 13:1-37.

Cataldo, C. D., T. R. Gardland and R. E. Wildung. 1983. Cadmium uptake kinetics in intact soybean plants. Plant Physiology. 73: 844-848.

Chen, H. M., C. R. Zheng, C. Tu and D. M. Zhou. 2001. Studies on loading capacity of agricultural soils for heavy metals and its applications in China. Applied Geochemistry. 16: 1397-1403.

Chen, M., Q. M. Lena and W. G. Harris. 1999. Baseline concentrations of 15 trace elements in Florida surface soils. Journal of Environmental Quality. 28: 1173-1181.

Chen, Y. H., Z. G. Shen and X. D. Li. 2004. The use of vetiver grass (Vetiveria zizanioides) in the phytoremediation of soils contaminated with heavy metals. Applied Geochemistry. 19: 1553-1565.

Ernst, W. H. O., J. A. C. Verkleij and H. Schat. 1992. Metal tolerance in plants. Acta Botanica Neerlandica. 41: 229249.

Ewa, I. O. M., M. O. A. Oladipo and L. A. Dim. 1999. Horizontal and vertical distribution of selected metals in the Kubani River, Nigeria as determined by Neutron Activation Analysis. Communications in Soil Science and Plant Analysis. 30: 1081-1090

Ewais, E. A. 1997. Effects of $\mathrm{Cd}, \mathrm{Ni}$ and $\mathrm{Pb}$ on growth, chlorophyll content and proteins of weeds. Biologia Plantarum. 39: 403-410.

Greger, M. and S. Lindberg. 1986. Effects of Cd and EDTA on young sugar beet, Beta vulgris. L. Cd uptake and sugar accumulation. Physiologia Plantarum. 66: 69-74.

He, Q. B. and B. R. Singh. 1993. Crop uptake of cadmium from phosphorous fertilizer. I. Yield and cadmium content. Water, Air, \& Soil Pollution. 74: 251-265.

Jeng, A. S. and B. R. Singh. 1993. Partitioning and distribution of cadmium and zinc in selected cultivated soil in Norway. Soil Science. 156:240-250.

Lee, B. D., B. J. Carter, N. T. Basta, B. Weaver. 1997. Factors influencing heavy metal distribution in six Oklahoma benchmark soils. Soil Science Society of America Journal. 61: 218-223.

Lehoczky, E. Z. and S. Horvath. 1998. Cadmium uptake by lettuce (Lactuca Sativa L.) in different soils. Communications in Soil Science and Plant Analysis. 29:1903-1912.

Lehoczky, E., I. Szabados and P. Marth. 1996. Cd content of plants as affected by soil $\mathrm{Cd}$ concentration. Communications in Soil Science and Plant Analysis. 27:1765-1777.

Lindsay, W. L. and W. A. Norvell. 1978. Development of a DTPA soil test for zinc, iron, manganese and copper. Soil Science Society of America Journal. 42: 421-428.

Logan, T. J. and R. H. Miller. 1983. Background levels of heavy metals in Ohio farm soils. Soil contamination analysis. Research. Circ. Ohio Agriculture. Research Dev. Ctr. Wooster. 275: 3-15.

Mahler, R. J., F. T. Bingham, G. Spoito and A. L. Page. 1980. Cadmium-enriched sewage sludge application to acid calcareous soil: Relation between treatment, $\mathrm{Cd}$ in saturation extract, and $\mathrm{Cd}$ uptake. Journal of Environmental Quality. 19: 357-364.

Moral, R., G. Palacios, I. Gomez, J. N. Pedreno and J. Mataix. 1994. Distribution and accumulation of heavy metals $(\mathrm{Cd}$, $\mathrm{Ni}$, and $\mathrm{Cr}$ ) in tomato plant. Fresenius Environmental Bulletin. 3:(7)395-399.

Nicholson, F. A. and K. C. Jones. 1994. Effect of phosphate fertilizers and atmospheric deposition on long-term changes in the cadmium content of soil and crops. Environmental Science Technology. 28: 2170-2175.

Oliver, M. A. 1997. Soil and human health: a review. European Journal of Soil Science. 48: 573-592.

Petterson, O. 1976. Heavy metals ion uptake by plants from nutrient solutions with metal ion, plant species and growth period variations. Plant and Soil. 45: 445-459.

Pezzarossa, B., G. Petruzzelli, F. Malorgio and F. Tognoni. 1993. Effect of repeated phosphate fertilization on the heavy metal accumulation in soil and plants under protected cultivation. Communications in Soil Science Plant Analysis. 24:2307-2319.

Reddy, C. N. and W. H. Patrick. 1977. Effect of redox potential and $\mathrm{pH}$ on the uptake of cadmium and lead by rice plants. Journal of Environmental Quality. 6: 259-262.

Schierup, H. and V. D. Larson. 1981. Macrophyte cycling of $\mathrm{Zn}, \mathrm{Cu}, \mathrm{Pb}$ and $\mathrm{Cd}$ in littoral zone of a polluted and nonpolluted lake. I. Availability uptake and translocation of heavy metals in phragmites australis (CAV). Trin. Aquatic Botany. 11: 179-210.

Taylor, M. D. 1997. Accumulation of cadmium derived from fertilizers in New Zealand soils. Science of the total Environment. 208: 123-126.

Todorova, E. I. and I. P. Dombalov. 1995. Production of phosphoric acid with low content of impurities. Fertilizer Research. 41: 125-128.

Walsh, L.M. (Ed.). 1971. Instrumental Methods for Analysis of Soils and Plant Tissue, Soil Science. Society of America, Madison, Wisconsin, 1971.

Webber, M. D. 2003. Cadmium in soil. Wastewater technology Centre, Burlington, Ont. On Internet, site http://res2.agr.ca

Weigel, H. J. and H. J. Jager. 1980. Different effects of cadmium in vitra and in vivo on anzyme activities in bean, phaseolus vulgaris L. Plants. Z. Pflanzen Physiol. 97: 103-113.

Zarcinas, B., M.Mclaughlin and G. Cozens. 1996. Cadmium in vegetable, legumes and oil seeds. On Internet, site http://www.Soils.Csiro. Au/cd-misc/cd-misc.htm. 
81

EL-GARAWANY, M. M AND M. R. MAHMOUD : CADMIUM ACCUMULATION IN SOIL AND IN SOME VEGETABLE ...

الملخص العربي

تراكم الكادميوم في التربة وبعض محاصيل الخضر التي يسببها السماد الفوسفاتي

20

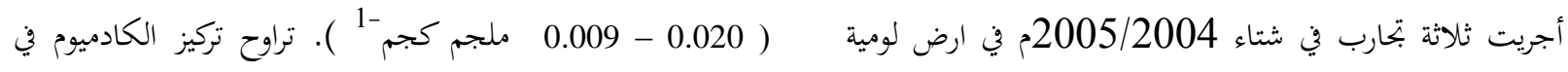

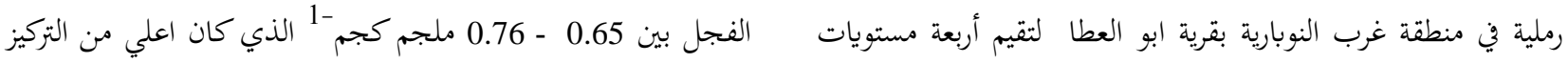

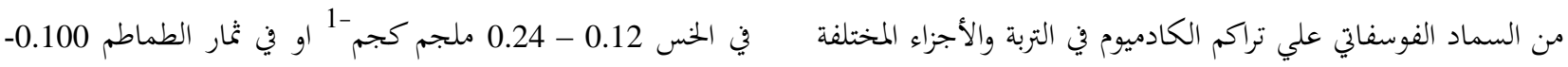

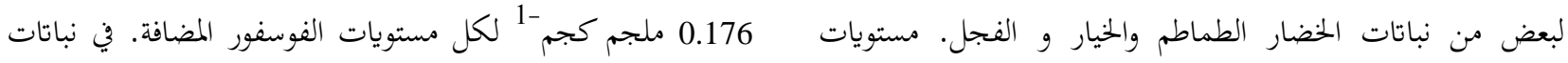

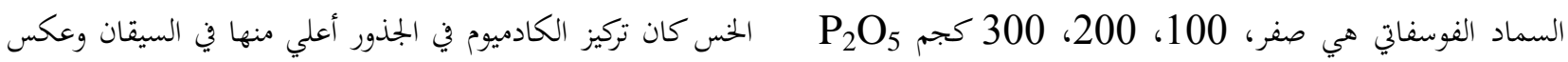

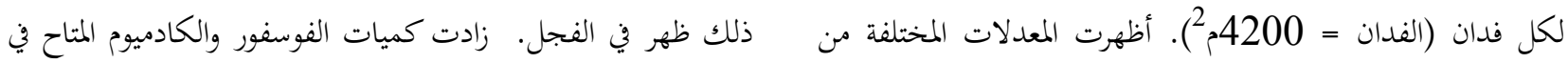

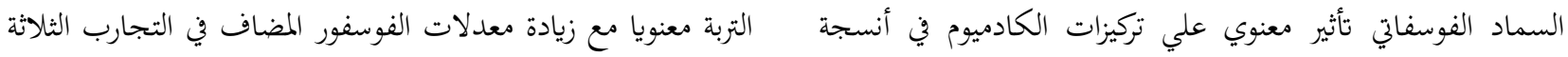

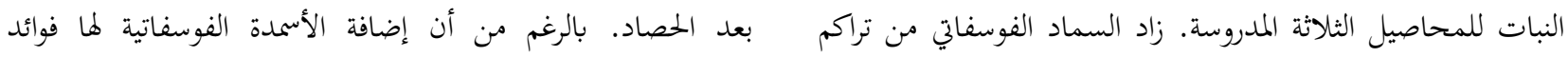

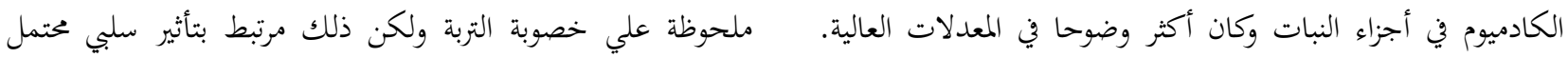

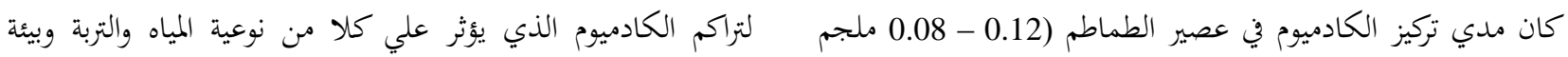

التربة.

كجم -1 ) أعلي من لخم ثمار الطماطم 